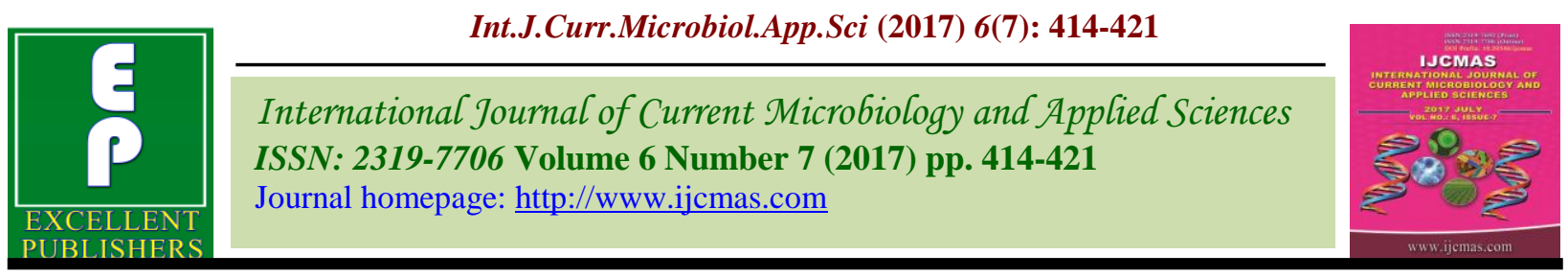

Original Research Article

https://doi.org/10.20546/ijcmas.2017.607.049

\title{
Harvest Index as Influenced by Genotype in Coriander under Godavari Zone
}

\author{
M.K. Nagappa ${ }^{1 *}$, B. Babu Rao ${ }^{2}$, M.K. Paramappa ${ }^{3}$ and T. Kranthi Kumar \\ Department of Horticulture, Dr. Y.S.R. Horticultural University, \\ Venkataramannagudem, West Godavari- 534101, A.P., India \\ *Corresponding author
}

Keywords

Coriander, Vegetative, Fruit, Harvest Index, Yield.

Article Info

Accepted:

04 June 2017

Available Online:

10 July 2017

\section{A B S T R A C T}

The performance of thirty genotypes was studied during rabi season in the year 2015-2016 at HCRI Venkataramannagudem, Andhra Pradesh in coriander (Coriandrum sativum L.). Maximum fresh weight of whole plant achieved in genotype LCC-200 (19.95 g) which was on par with LCC-325 (19.43 g), maximum dry weight (3.30 g) was observed in LCC-317, genotypes LCC-319 had maximum number of schizocarps per umbel (41.58), genotype LCC-317 produced more number of schizocarps per umbellets (5.90), genotype AD-1 produced less number of schizocarps per umbellets (3.90), genotype LCC-317 produced more number of schizocarps per plant (228.04) which was on par with LCC-321 (218.02), highest herbage yield per plant $(8.12 \mathrm{~g})$ was recorded by the genotype Shiggaon-3, maximum biomass production (46.35 g) was recorded by LCC-321 and genotype commercial check Suguna recorded maximum harvest index (57.75). Whereas maximum yield was achieved in genotype Suguna (commercial check) $(502.17 \mathrm{~kg} / \mathrm{ha})$ was significantly superior over than other genotypes evaluated.

\section{Introduction}

Coriander (Coriandrum sativum L.) originated in Mediterranean region and spread to Europe, Asia, North and South - America and Australian countries, is an important seed spice crop. The crop grows in tropics and requires a cool but comparatively dry frostfree climate, particularly at flowering and seed formation stages (Sharma and Sharma, 2004). It is cultivated throughout the world both for seed and leaf purpose. It is grown in more than fifty countries with India at ranking 1st, both in area and production followed by Mexico, China, former Soviet Union, Central America and South America (Morales-Payan,
2011). It is grown in almost all the states of India either for grain or leaf or dual purpose. In India the crop is cultivated mainly in Rajasthan, Madhya Pradesh, Andhra Pradesh, Orissa, Tamil Nadu and Karnataka on an area of 5.43 lakh ha with a production of 5.24 lakh metric tonnes (Tiwari, 2014). The average crop productivity is only $965 \mathrm{~kg} \mathrm{ha}^{-1}$ and is much lower in rainfed farming situation (477 $\left.\mathrm{kg} \mathrm{ha}^{-\mathbf{1}}\right)$. The low productivity under rainfed situation is mainly due to terminal moisture stress that affects growth and productivity. Growing coriander in rainfed in Godavari zone farming situation demands highly 
productive types with short (75 days) to medium (85-100 days) duration for cultivation. Locally grown indigenous genotypes are low in productivity and give poor returns to the farmers. Critical evaluation of available selections of improved types with high yield potential/ traits is of great value to the breeder for crop improvement (Moniruzzaman, 2013). Mengesha and Getinetalemaw (2010) evaluated some Ethiopian coriander genotypes and reported that identification and evaluation of elite or promising genotypes for yield and quality is an important crop improvement strategy. Sarada and Giridhar (2009) opined that it is possible to realize $1500 \mathrm{~kg} \mathrm{ha}^{-1}$ under rainfed conditions if a proper combination of genotypes and management are available to the farmers. Keeping this in view, the present study was undertaken to evaluate promising diverse genotypes from Godavri zone of Andhra Pradesh.

\section{Materials and Methods}

The present investigation was conducted during the year 2015-16 at Horticulture College and Research Institute, Dr. Y.S.R Horticultural

University, Venkataramannagudem, West Godavari District. The location falls under Agroclimatic zone-10, humid, East Coast Plain and Hills (Krishna-Godavari zone) with an average annual rainfall of $900 \mathrm{~mm}$ at an altitude of $34 \mathrm{~m}$ (112 feet) above mean sea level. The geo-graphical situation is $16^{\circ} 63$ $120 " \mathrm{~N}$ latitude and $81^{\circ} 27^{\prime} 568^{\prime \prime}$ E longitude. It experiences hot humid summer and mild winter. A total of thirty genotypes were taken for evaluation study out of which fifteen genotypes were sourced from HRS Devihosur (Haveri) Karnataka (Ranibennur-1, Ranibennur-2, Ranibennur-3, Byadagi-1, Hangel-1, Hangel-2, Savanur-1, Savanur-2, Savanur-3, Hirekerur-1, Hirekerur-2, Hirekerur-3, Shiggaon-1, Shiggaon-2,
Shiggaon-3) whereas, the rest of the accessions were sourced from HRS Lam Guntur, Andhra Pradesh (LCC-200, LCC331, LCC-321, LCC-323, LCC-325, LCC334, LCC-335, LCC-316, LCC-328, LCC320, LCC-317, LCC-319 and LCC-322; and two checks viz., AD-1 (local check) and Suguna (commercial check). The experiment was laid out in RBD with two replications and thirty genotypes. The observations were recorded on various growth, seed yield and quality parameters. The crop was raised at a plant spacing of $30 \mathrm{~cm} \times 15 \mathrm{~cm}$. The seed were sown during 2nd of November and harvested during $2^{\text {nd }}$ fortnight of February. A basal fertilizer dose of $35 \mathrm{~kg} \mathrm{~N}, 35 \mathrm{~kg}$ P2O5 and $35 \mathrm{~kg} \mathrm{~K} 2 \mathrm{O}$ ha- 1 was given at the time of soil preparation each year. Soil was prepared to a fine tilth and the seed sown in rows using a labor. At 20 days after sowing (DAS), the plants were thinned $15 \mathrm{~cm}$ apart to maintain a uniform plant population. Need-based plant protection measures were taken up to raise a healthy crop. Plants were uprooted at harvest. Threshing was done with wooden sticks and seeds winnowed to remove any impurities. Five randomly selected plants from each replication were used for recording of yield attributes. Fresh and dry weight of whole plant was measured with the help of a balance weight machine and schizorarps umbel-1 was assessed by counting from the plant samples. Total grain yield was obtained from net plot yield which was converted to per hectare yield.

\section{Results and Discussion}

\section{Fresh and dry weight of whole plant}

The data of 2015-2016 year indicated that the genotypes under evaluation varied significantly with respect to qualitative and seed yield attributes studied. The genotypes differed significantly in vegetative and seed yield (Table 1). The maximum whole plant 
fresh weight was recorded at 75 DAS (19.95 g) in the genotype LCC-200 which was on par with LCC-325 (19.43 g) whereas, the minimum value (7.32 g) was observed in Ranibennur-1 followed by Ranibennur-2 (9.02 g). Nine genotypes had significantly maximum fresh weight as compared to the commercial check Suguna (16.89 g).

The maximum dry weight $(3.30 \mathrm{~g})$ was observed in LCC-317 at 75 DAS which was on par with LCC-323 (3.27 g), LCC-328 (3.14 g), LCC-320 (3.06 g), Shiggaon-3 (2.97 g), Local check AD-1 (2.93 g), LCC-331 $(2.88 \mathrm{~g})$, LCC-200 (2.87 g) and LCC-316 $(2.86 \mathrm{~g})$. The minimum dry weight of whole plant was found in Ranibennur-1 (1.47 g) which was on par with Byadagi-1 (1.58 g), Hangel-1 (1.59 g), Hangel-2 (1.67 g), Savanur-2 (1.72 g), Hirekerur-2 (1.73 g), Savanur-3 (1.82 g), Ranibennur-3 (1.83 g), Ranibennur-2 (1.99 g) and Shiggaon$2(2.0 \mathrm{~g})$.

A total of five genotypes had significantly higher dry weight of whole plant than the local check AD-1(4.89 g). Leaf area is the area of assimilation of light energy into chemical energy through a process known as photosynthesis. The effectiveness of photosynthetic apparatus inside the plant is quantitatively delimited by leaf area per plant. Since the photosynthetic products contribute to the protoplasm inside the cells, tissues and organs, it is the area of assimilation that governs the gross material ingested and synthesised within the plant system.

Therefore the fresh weight of whole plant is dependent on leaf area per plant and also the number of leaves per plant. Fresh weight of plant largely includes moisture in the cellular environment. The tenacity with which the moisture is held can be different in different cells or tissues or organs and also largely in genotypes. A genotype that loses moisture loosely may be left with very little dry matter and similarly when the vegetative parts are stronger and not plump in any accession, they may show slightly more dry matter disproportioning with its corresponding fresh weight.

However, there is slightly similar ranking or at par ranking between fresh weight and dry weight values among the genotypes in the present study. Similar influence of these characters and their interdependence was also compiled by Meena et al., (2014) in coriander.

\section{Schizocarps}

Significant differences were noticed among the genotypes with respect to number of schizocarps per umbel (Table 1). The genotypes LCC-319 had maximum number of schizocarps per umbel (41.58) which was on par with LCC-316 (39.08). The genotype LCC-320 had minimum number of schizocarps per umbel (23.33) which was on par with Suguna (24.36), Hirekerur -1 (25.96) and Ranibennur-2 (26.23). Three genotypes were significantly more number of schizocarps per umbel as compared to local check AD-1 (36.78).

Significant differences were observed among the genotypes with respect to number of schizocarps per umbellets (Table 1). The genotype LCC-317 produced more number of schizocarps per umbellets (5.90). The genotype AD-1 produced less number of schizocarps per umbellets (3.90).

Four genotypes produced more number of schizocarps per umbellets as compared to the commercial check Suguna (5.32). Significant differences were observed among the genotypes with respect to number of schizocarps per plant (Table 1). The genotype 
LCC-317 produced more number of schizocarps per plant (228.04) which was on par with LCC-321 (218.02). The genotype Shiggaon-3 produced less number of schizocarps per plant (144.05) on par with LCC-323 (146.37) and LCC-320 (147.28).

Four genotypes produced more number of schizocarps per plant as compared to the commercial check Suguna (213.06). During reproductive phase, coriander produces umbellets in each umbel and these umbellets bear the schizocarps.

It is the effectiveness of the schizocarp bearing points on the umbellets that decides the productivity of each umbel. The number of umbellets per umbel is not showing very wide variations perhaps it may be a crop bound character and not so dynamic with genotype. The accessions having greater leaf area and long duration of flowering are naturally vested with a great amount of time in which they can divert assimilates into the reproductive parts and therefore would be able to produce a higher quantity of fruits (schizocarps) in each plant.

In the present study the accessions with merit in leaf area and other vegetative parameters coupled with long crop duration are found to show a larger quantity of grain production compared to other accessions. The association of these parameters with grain yield was also observed among different varieties of coriander by Meena et al., (2014) in coriander.

Fig.1 Biological, economic and harvest index among coriander genotypes

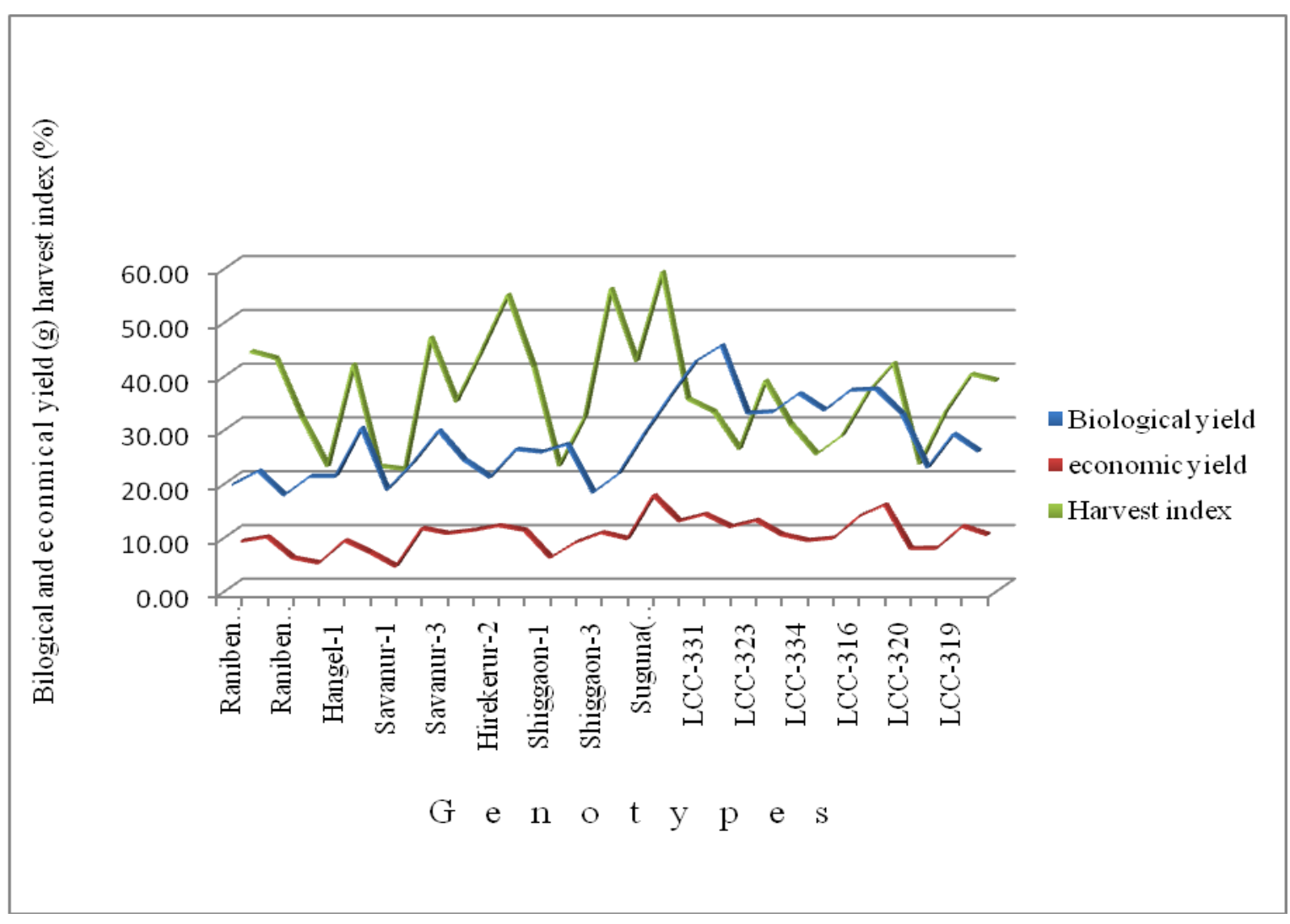


Table.1 Vegetative and fruiting traits in coriander genotypes

\begin{tabular}{|c|c|c|c|c|c|}
\hline Genotypes & $\begin{array}{l}\text { Fresh } \\
\text { weight } \\
\text { (g) }\end{array}$ & $\begin{array}{l}\text { Dry } \\
\text { weight } \\
(\text { g) }\end{array}$ & $\begin{array}{l}\text { Number of } \\
\text { schizocarps } \\
\text { per umbel }\end{array}$ & $\begin{array}{l}\text { Number of } \\
\text { schizocarps } \\
\text { per plant }\end{array}$ & \begin{tabular}{|l|} 
Number of \\
schizocarps per \\
umbellets
\end{tabular} \\
\hline Ranibennur-1 & 7.32 & 1.47 & 31.50 & 169.92 & 4.00 \\
\hline Ranibennur-2 & 9.02 & 1.99 & 26.23 & 161.73 & 4.38 \\
\hline Ranibennur-3 & 10.55 & 1.83 & 31.93 & 188.51 & 4.84 \\
\hline Byadagi-1 & 10.04 & 1.58 & 29.33 & 170.10 & 4.26 \\
\hline Hangel-1 & 12.14 & 1.59 & 26.67 & 160.27 & 4.55 \\
\hline Hangel-2 & 11.06 & 1.67 & 29.46 & 211.90 & 4.90 \\
\hline Savanur-1 & 12.38 & 1.97 & 30.14 & 193.07 & 5.00 \\
\hline Savanur-2 & 12.75 & 1.72 & 27.00 & 186.56 & 5.40 \\
\hline Savanur-3 & 12.13 & 1.82 & 36.49 & 192.78 & 5.10 \\
\hline Hirekerur-1 & 9.83 & 2.04 & 25.96 & 159.79 & 5.20 \\
\hline Hirekerur-2 & 11.69 & 1.73 & 28.62 & 194.74 & 4.26 \\
\hline Hirekerur-3 & 15.18 & 2.27 & 32.83 & 206.91 & 4.78 \\
\hline Shiggaon-1 & 14.03 & 2.43 & 33.96 & 187.27 & 4.85 \\
\hline Shiggaon-2 & 16.79 & 2.00 & 28.98 & 170.99 & 4.98 \\
\hline Shiggaon-3 & 15.43 & 2.97 & 32.37 & 212.08 & 5.12 \\
\hline AD-1 (check) & 14.78 & 2.93 & 36.78 & 144.05 & 3.90 \\
\hline Suguna (check) & 16.89 & 2.71 & 24.36 & 213.06 & 5.32 \\
\hline LCC-200 & 19.95 & 2.87 & 32.89 & 184.90 & 5.00 \\
\hline LCC-331 & 18.24 & 2.88 & 36.96 & 213.48 & 4.76 \\
\hline LCC-321 & 19.07 & 2.63 & 35.86 & 218.02 & 4.85 \\
\hline LCC-323 & 18.93 & 3.27 & 35.62 & 146.37 & 4.90 \\
\hline LCC-325 & 19.43 & 2.66 & 32.55 & 191.14 & 4.38 \\
\hline LCC-334 & 17.89 & 2.54 & 34.02 & 209.08 & 4.60 \\
\hline LCC-335 & 18.34 & 2.53 & 35.78 & 216.61 & 5.21 \\
\hline LCC-316 & 17.58 & 2.86 & 39.08 & 171.72 & 5.50 \\
\hline LCC-328 & 18.64 & 3.14 & 34.76 & 207.26 & 5.26 \\
\hline LCC-320 & 16.36 & 3.06 & 23.33 & 147.28 & 4.70 \\
\hline LCC-317 & 16.84 & 3.30 & 32.50 & 228.04 & 5.90 \\
\hline LCC-319 & 15.00 & 2.61 & 41.58 & 208.74 & 5.60 \\
\hline LCC-322 & 16.44 & 2.56 & 33.12 & 197.80 & 5.32 \\
\hline Mean & 14.82 & 2.39 & 32.02 & 188.81 & 4.89 \\
\hline $\mathrm{S} \mathbf{E m} \pm$ & 0.27 & 0.19 & 1.01 & 3.90 & 0.10 \\
\hline CD & 0.79 & 0.54 & 2.92 & 11.29 & 0.29 \\
\hline
\end{tabular}


Int.J.Curr.Microbiol.App.Sci (2017) 6(7): 414-421

Table. 2 Herbage yield, biomass production, harvest index and Grain yield traits in coriander genotypes

\begin{tabular}{|c|c|c|c|c|c|c|}
\hline Genotypes & $\begin{array}{l}\text { Herbage } \\
\text { yield }(\mathrm{g})\end{array}$ & $\begin{array}{c}\text { Biomass } \\
\text { production at } \\
\text { harvest }(\mathrm{g})\end{array}$ & $\begin{array}{c}\text { Harvest } \\
\text { index }(\%)\end{array}$ & $\begin{array}{c}\text { Grain yield } \\
\text { per } \\
\text { plant }(\mathrm{g})\end{array}$ & $\begin{array}{c}\text { Grain } \\
\text { yield per } \\
\text { plot }(\mathrm{g})\end{array}$ & $\begin{array}{c}\text { Grain } \\
\text { yield per } \\
\text { ha }(\mathrm{kg})\end{array}$ \\
\hline Ranibennur-1 & 5.36 & 20.50 & 42.92 & 8.80 & 105.60 & 255.07 \\
\hline Ranibennur-2 & 5.20 & 23.00 & 41.67 & 9.59 & 115.03 & 277.84 \\
\hline Ranibennur-3 & 4.33 & 18.51 & 30.61 & 5.67 & 82.50 & 199.28 \\
\hline Byadagi-1 & 4.49 & 22.00 & 21.57 & 4.75 & 74.64 & 180.29 \\
\hline Hangel-1 & 5.78 & 22.00 & 40.56 & 8.93 & 107.10 & 258.70 \\
\hline Hangel-2 & 5.41 & 31.01 & 21.59 & 6.70 & 94.15 & 227.42 \\
\hline Savanur-1 & 6.32 & 19.50 & 21.02 & 4.10 & 65.80 & 158.94 \\
\hline Savanur-2 & 5.60 & 24.50 & 45.56 & 11.17 & 133.98 & 323.62 \\
\hline Savanur-3 & 5.83 & 30.50 & 33.61 & 10.25 & 123.00 & 297.10 \\
\hline Hirekerur-1 & 6.47 & 25.00 & 43.26 & 10.82 & 129.78 & 313.48 \\
\hline Hirekerur-2 & 6.51 & 21.82 & 53.49 & 11.67 & 140.07 & 338.33 \\
\hline Hirekerur-3 & 5.80 & 27.01 & 40.14 & 10.84 & 130.10 & 314.24 \\
\hline Shiggaon-1 & 6.87 & 26.51 & 21.68 & 5.75 & 79.80 & 192.75 \\
\hline Shiggaon-2 & 5.95 & 27.95 & 30.86 & 8.63 & 103.53 & 250.07 \\
\hline Shiggaon-3 & 8.12 & 19.00 & 54.60 & 10.38 & 124.50 & 300.72 \\
\hline AD-1 (check) & 7.61 & 22.50 & 41.10 & 9.25 & 110.97 & 268.04 \\
\hline Suguna (check) & 7.12 & 30.00 & 57.75 & 17.33 & 207.90 & 502.17 \\
\hline LCC-200 & 7.59 & 36.90 & 34.06 & 12.57 & 150.84 & 364.35 \\
\hline LCC-331 & 7.32 & 43.43 & 31.77 & 13.80 & 165.60 & 400.00 \\
\hline LCC-321 & 6.31 & 46.35 & 24.81 & 11.50 & 138.00 & 333.33 \\
\hline LCC-323 & 6.32 & 33.74 & 37.52 & 12.66 & 151.92 & 366.96 \\
\hline LCC-325 & 7.63 & 34.00 & 29.34 & 9.98 & 119.70 & 289.13 \\
\hline LCC-334 & 5.78 & 37.41 & 23.86 & 8.93 & 107.10 & 258.70 \\
\hline LCC-335 & 7.25 & 34.31 & 27.33 & 9.38 & 112.50 & 271.74 \\
\hline LCC-316 & 5.89 & 38.01 & 35.36 & 13.44 & 161.25 & 389.49 \\
\hline LCC-328 & 8.06 & 38.22 & 40.82 & 15.60 & 187.20 & 452.17 \\
\hline LCC-320 & 7.08 & 33.66 & 22.05 & 7.42 & 98.54 & 238.02 \\
\hline LCC-317 & 6.77 & 23.61 & 31.67 & 7.48 & 96.72 & 233.62 \\
\hline LCC-319 & 7.01 & 29.86 & 38.68 & 11.55 & 138.60 & 334.78 \\
\hline LCC-322 & 6.60 & 26.63 & 37.55 & 10.00 & 120.00 & 289.86 \\
\hline Mean & 6.41 & 28.92 & 35.23 & 9.96 & 119.55 & 296.01 \\
\hline S Em \pm & 0.32 & 1.85 & 1.12 & 0.80 & 12.10 & 25.88 \\
\hline CD & 0.94 & 5.36 & 3.25 & 2.32 & 34.99 & 74.85 \\
\hline
\end{tabular}


Herbage yield, biomass production and harvest index

The genotypes varied significantly in terms of herbage yield per plant at 45DAS (Table 2). The highest herbage yield per plant $(8.12 \mathrm{~g})$ was recorded by the genotype Shiggaon-3 which was on par with LCC-328 (8.06 g), LCC-325 (7.63 g), AD-1 (7.61 g), LCC-200 $(7.59 \mathrm{~g})$ and LCC-331 (7.32 g). The genotype Ranibennur-3 produced the lowest herbage yield per plant $(4.33 \mathrm{~g}$ ) on par with Byadagi-1 $(4.49 \mathrm{~g})$ and Ranibennur-2 (5.20 g). Six genotypes had significantly more herbage yield per plant as compared to the local check AD-1 (7.61 g). The biomass production exhibited significant differences among the genotypes studied (Table 2 and Fig. 1). Maximum biomass production (46.35 g) was recorded by LCC-321 which was on par with LCC-331 (43.43 g).

The genotype Ranibennur-3 recorded the lowest biomass production $(18.51 \mathrm{~g})$ which was on par with Shiggaon-3 (19.00 g), Savanur-1 (19.50 g), Rabibennur-1 (20.50 g), Hirekerur-1 (21.82 g), Byadagi-1 (22.00 g), Hangel-1 (22.00 g), AD-1 (22.50 g) and Ranibennur $-2 \quad(23.00 \quad \mathrm{~g})$. A total 12 genotypes had significantly maximum biomass production as compared to the commercial check Suguna (30.00 g). The differences noticed in respect of harvest index among the genotypes under study were found to be significant (Table 2 and Fig. 1).

The genotype commercial check Suguna recorded maximum harvest index (57.75) which was on par with Shiggaon-3 (54.60). The genotype Savanur-1 recorded minimum harvest index (21.02) on par with Byadagi-1 (21.57), Hangel-2 (21.59), Shiggaon-1 (21.68), LCC-320 (22.05) and LCC-334 (23.86). Genotype Suguna had significantly maximum harvest index as compared to other than all genotypes (57.75).

\section{Grain yield}

The genotypes varied significantly in terms of grain yield per plant (Table 2 and Fig. 1). The highest grain yield per plant (17.33 g) was recorded by commercial check Suguna which was on par with LCC-328 (15.60 g). The genotype Savanur-1 produced the lowest grain yield per plant $(4.10 \mathrm{~g})$ on par with Byadagi-1 (4.75 g), Ranibennur-3 (5.67 g) and Shiggaon-1 $(5.75 \mathrm{~g})$. Twenty nine genotypes had significantly lower grain yield per plant as compared to the commercial check Suguna (17.33 g). The grain yield per plot exhibited significant differences among the genotypes studied (Table 2). Maximum grain yield per plot at $(207.90 \mathrm{~g})$ was recorded by Suguna which was on par with LCC-328 (187.20 g). The genotype Savanur-1 recorded the lowest grain yield per plot $(65.80 \mathrm{~g})$ on par with Byadagi-1 (74.64 g), Shiggaon-1 (79.80 g), Ranibennur3 (82.50 g), Hangel-2 (94.15), LCC-317 (96.72) and LCC-320 (98.50 g).The commercial check Suguna genotype had significantly maximum grain yield per plot as compared to the all other genotypes $(207.90 \mathrm{~g})$. The grain yield per hectare exhibited significant differences among the genotypes studied (Table 2). Maximum grain yield per hectare $(502.17 \mathrm{~kg})$ was recorded by Suguna which was on par with LCC-328 $(452.10 \mathrm{~kg})$. The genotype Savanur-1 recorded the lowest grain yield per hectare $(158.94 \mathrm{~kg})$ on par with Byadagi-1 (180.29 kg), Shiggaon-1 (192.75 kg), Ranibennur-3 (199.28 kg), Hangel-2 (227.42 kg) and LCC$317(233.62 \mathrm{~kg})$. The commercial Suguna genotypes had significantly maximum grain yield per hectare as compared to the all other genotypes $(502.17 \mathrm{~kg})$. The boldness of grain and its weight and oil content are dependent on how it was able to drag the assimilates from different sources and also perhaps due to its genetic makeup. It is the speed and steady flow of the photosynthetic 
products that decides over time the size of the fruits and its weight. Therefore, these quality parameters are necessarily influenced by greater values of vegetative parameters as evident from the data obtained on these parameters from various genotypes. Bold grains and in higher quantities would definitely lead to greater grain yield per plant which in turn govern corresponding top rank of a genotype in grain yield per plot and per hectare. However, grain quality has no bearing on total yield or quantity produced by an accession. In the present study, it is evident that genotypes had independent ranking with regard to quality parameters as against grain yield. Yield is a complex character and is influenced by several attributing parameters. Similar trends were also noted by Meena et al., (2014) in coriander and Anubha et al., (2013) in fenugreek.

\section{References}

Anubha, J, Balraj Singh, Solanki K.R, Saxena, N.S. and Kale, K.R. 2013. Genetic variability and character association in fenugreek (Trigonell foenum-graecum L.). Int. J. Seed Spices. 3(2): 22-28.

Mengesha, B., and Getinetalemaw, G. 2010. Variability in Ethiopian coriander accessions for agronomic and quality traits. Afr. Crop Sci. J., 18 (2): 43-49.

Meena, K.Y, Kale S.V. and Meena P.O. 2014. Correlation coefficient and path analysis in coriander. Int. J. Sci. Res. Publ., 4(6): 2250-3153.

Moniruzzaman, M., Rahman, M.M., Hossain, M.M., Karim, A.S. and Khaliq, Q.A. 2013. Evaluation of coriander (Coriandrum sativum L.) genotypes for seed yield and yield contributing characters. Bangladesh J. Agri. Res., 38: 189-202.

Morales-Payan, J.P. 2011. Herbs and leaf crops: Cilantro, broadleaf cilantro and vegetable amaranth. pp. 1-28. In: Soils, Plant Growth and Corp Production, Vol. 3 (Ed. W.H. Verheye). Eolss Publishers, Oxford, UK.

Mourya, P.B, Yadav, K.B, Pandey, P.V. and Yadav S.P. 2015. Correlation and path analysis in Fenugreek (Trigonella foenumgraecum L.). Res. Environ. Life Sci., 8(4): 569-70.

Nilkolay, D. and Boryana, D. 2014. Heritability and correlation coefficient analysis for fruit yield and its components in coriander (Coriandrum sativum L.). Turk. J. Agri. Natural Sci., 1: 618-22.

NHB. 2014. Commodity wise Status. Indian Horticulture Database. National Horticulture Board, New Delhi.

Sarada, C. and Kalidasu, G. 2009. Elite genotypes of coriander suitable for rain fed cultivation in Andhra Pradesh. Annals Plant Physiol., 23: 174-176.

Sarada, C. and Kalidasu, G. 2011. Threats in production of coriander (Coriandrum sativum) in Andhra Pradesh. Journal of Spices and Aromatic Crops, 17: 158-162.

Sharma, M.M. and Sharma, R.K. 2004. Coriander. pp. 145-161. In: Hand book of Herbs and Spices. (Ed. K.V. Peter). Wood head Publishing Limited, Cambridge, England.

Tiwari, R.K. 2014. Crop-wise area, production and productivity of major spice crops in India during 2010-11, 2011-12 and 201213. In: Indian Horticulture Database, 2013 (Eds. N.C.

\section{How to cite this article:}

Nagappa, M.K., B. Babu Rao, M.K. Paramappa and Kranthi Kumar, T. 2017. Harvest Index as Influenced by Genotype in Coriander under Godavari Zone. Int.J.Curr.Microbiol.App.Sci. 6(7): 414-421. doi: https://doi.org/10.20546/ijcmas.2017.607.049 